\title{
SULALATUS SALATIN AND TUN \\ PERAK'S CHARISMA IN THE \\ PRACTICE OF THE LAWS OF \\ NUSANTARA MULTIETHNIC \\ SOCIETY
}

(Sulalatus Salatin dan Karisma Tun Perak dalam Amalan

Undang-Undang Masyarakat Pelbagai Etnik Nusantara)

\author{
Jelani Harun \\ jelani@usm.my \\ School of Humanities, \\ Universiti Sains Malaysia.
}

\begin{abstract}
In the 15th century, Malacca emerged as a city that became the focus of traders and travellers from all corners of the Nusantara. At that time, the states under the protection of Malacca and anyone who came to Malacca were subject to the laws of the Malacca Sultanate. This has been referred to many times by the author of Sulalatus Salatin, in the narration of events involving Malacca's relations with other states in the Nusantara world, and at the same time highlighting the practice of laws which took place in the multiethnic society residing in Malacca. Harshness is the general characteristic in the implementation of laws and this view is supported by works on Malay governance such as Taj-Salatin, Bustan al-Salatin and Thamarat-Muhimmah. However, harshness not accompanied by fairness and wisdom can lead to cruelty. This issue became part of the focus of Sulalatus Salatin's author's thinking while describing several myths, conflicts and philosophies of justice of the Malay rulers in Singapore and Malacca which is closely linked to attitude, leadership and knowledge of the rulers and leaders. This article will reevaluate the issue by drawing attention to the charisma of Tun Perak in the implementation of laws of the Malay sultanate, either towards the multiethnic society in the Nusantara or in the context of those residing in Malacca, in
\end{abstract}


which the issues of harshness of laws are entangled, counterbalanced and intertwined with many incidents of slander, sedition and corruption that could destroy the history of Malay culture.

Keywords: Tun Perak, laws, governance, historiography, philosophy, slander, corruption

\begin{abstract}
Abstrak
Pada abad ke-15 yang lalu, Melaka muncul sebagai sebuah negara kota tumpuan kedatangan para pedagang dan penghijrah dari seluruh pelosok rantau alam Nusantara. Ketika itu, semua negeri yang berada di bawah naungan Melaka dan sesiapa sahaja yang datang ke Melaka akan tertakluk di bawah perintah undang-undang adat Kesultanan Melaka. Hal ini banyak disuratkan oleh pengarang Sulalatus Salatin melalui peristiwa perhubungan Melaka dengan kerajaan-kerajaan yang berada di alam Nusantara, di samping memusatkan perhatian kepada amalan undang-undang yang berlaku dalam kalangan masyarakat pelbagai etnik yang tinggal di Melaka. Kekerasan menjadi satu ciri umum pelaksanaan undang-undang yang turut mendapat dukungan dalam karya-karya ketatanegaraan Melayu seperti Taj al-Salatin, Bustan al-Salatin dan Thamarat al-Muhimmah. Walau bagaimanapun, kekerasan tanpa diikuti dengan keadilan dan kebijaksanaan akan menjurus kepada perbuatan kezaliman. Persoalan ini menjadi sebahagian daripada pusat pemikiran pengarang Sulalatus Salatin ketika memerikan beberapa mitos, konflik dan falsafah keadilan istana raja-raja Melayu di Singapura dan Melaka yang bertaut rapat dengan sikap, kepimpinan dan keilmuan rajaraja dan para pembesarnya. Makalah akan menilai semula persoalan ini dengan memusatkan perbincangan kepada karisma Tun Perak dalam amalan undang-undang kesultanan Melayu, sama ada terhadap masyarakat pelbagai etnik Nusantara ataupun dalam konteks masyarakat yang tinggal di Melaka, dan dalam isu-isu tentang kekerasan undang-undang yang bercampur-baur, bertimbang-tara dan berselirat dengan pelbagai peristiwa fitnah, hasutan dan rasuah yang boleh meruntuhkan sejarah peradaban Melayu.
\end{abstract}

Kata kunci: Tun Perak, undang-undang, ketatanegaraan, historiografi, falsafah, fitnah, rasuah

\title{
INTRODUCTION
}

Sulalatus Salatin is one of the earliest works that present the Malay society's interaction with a variety of world communities such as those from the Middle East, Portugal, India and China. The arrival of traders and travellers 
from the Middle East, India (known as the Indian Continent and Indians) and China to Malacca brought some influence from their way of life to Malacca, including the the practice of their laws. Punishments such as to be submerged in water, or the hand is put in oil or lead originated from Hindu beliefs, especially from the Laws of Manu. ${ }^{1}$ Impalement was a direct influence from the punishment which originated in China. The Islamization of Malacca sultans by Syed Abdul Aziz who came from Jeddah succeeded in converting the rulers, the elites and the people of Malacca (A. Samad, 1996:73) and thus established the Islamic way of life in Malacca that included its laws and customs.

Compared to the Middle East, Europe and Asia, the focus of Sulalatus Salatin is on the way of life in the Nusantara or the Malay world of Nusantara which was rich in ethnic diversity. ${ }^{2}$ Many of the governments that existed in Nusantara at that time are mentioned or described by the author of Sulalatus Salatin, such as those of Java, Siam, Legor, Patani, Inderagiri, Sulawesi, Pasai, Haru, Acheh, Pidir, Lingga, Bintan, Maluku, Kampar, Sunda, Siak, Mengkasar, Brunei, Singapore, Campa and others. All these governments had a king, state, and citizens of their own, although there were some that were under the control of other governments. Apart from Goa in India (where Alfonso d' Albuquerque resided) there is also Goa in Sulawesi (A. Samad, 1996:101).

In Malay literature, the works that are categorized as historiographic or Malay historical literature, have attained a prominent and unique position. These works are original Malay literature from the minds of court writers on Malay history and civilization that encompass the origin of Malay rulers, the country, the religion, the customs, the laws, the culture etc. Almost the whole of the Malay historiographic works that are in existence today have been proclaimed as a heritage of great Malay works because of the strength of its contents and the high value of its artistic writing. In this context, Sulalatus Salatin by Tun Seri Lanang is one of the best Malay historiographies describing the history and culture as well as the rise and fall of the sultanates in Malacca and Johore in the 15th and 16th centuries. ${ }^{3}$

Around the early 15 th century, Malacca was one of the city states that attracted many people from all over Nusantara to settle down there, until a large multiethnic community evolved. ${ }^{4}$ At the same time, all manners of life, customs and laws in Malacca became known to all the people there and later spread to other states in Nusantara. 
An interesting depiction of the multiethnicity of Malacca can be seen in the incident whereby Sultan Mansur' Shah's palace was destroyed by fire. The sultan then ordered his subjects to build a new palace by recruiting skilled craftsmen from various races. The result of the work done by the craftsmen of various races would certainly produce a palace that showed all kinds of patterns and designs, and can probably be regarded as a palace of Nusantara Malays at that time. The description in Sulalatus Salatin is as follows:

Maka Sultan Mansur Syah pun memberi titah pada bendahara menyuruh berbuat istana dan balairung. Dalam sebulan itu juga dikehendaki sudah. Maka bendahara pun mengerahkan orang membuat istana dan balairung. Orang Ungaran berbuat istana besar, orang Sugal sebuah istana, dan orang Buru sebuah istana, dan orang Suir sebuah istana, dan orang Pancur Serapung membuat balairung, orang Sudir membuat balai penghadapan, dan orang Merba membuat penanggahan, dan orang Sawang membuat balai jawatan di sisi balairung, orang Kundur membuat balai apit pintu keduanya, dan orang Suntai berbuat balai kendi, orang Melai berbuat pemandian, orang Upang berbuat bangsal gajah, orang Tungkal membuat masjid, orang Bintan membuat pagar istana, orang Muar membuat kota wang. Adapun istana itu baik pula daripada dahulu.

(Therefore Sultan Mansur Shah gave out the order to the bendahara (grand vizier) to build a palace and a throne room. It had to be ready in one month. The bendahara then commanded the people to build a a palace and a throne room. The Ungarans built a big palace, the Sugals a palace, the Burus a palace, and the Suirs a palace and the people of Pancur Serapung built the throne room, the Sudirs built the entry hall, the Merbas built the kitchen and the Sawangs made the official hall at the side of the throne room, the Kundurs made the middle reception room and the Suntais the "kendi" hall, the Melais made the bathrooms, the Upangs the elephant stalls, the Tungkals, the mosque, the Bintans, the fence, the Muarians the palace rooms. This palace was much better than the previous one.)

Apart from Sulalatus Salatin, the multiethnicity of Nusantara Malay society was often described in historiographic works such as Hikayat Misa Melayu by Raja Chulan in Perak in 1784, Tuhfat al-Nafis by Raja Ali Haji in Riau in 1865 and Hikayat Patani written in Patani around the middle of the 18th century. For instance, Raja Chulan in Hikayat Misa Melayu described a great deal about the multiethnicity in Perak in the 18th century, specifically during the reign of Sultan Iskandar Dzulkarnain Shah (1750-1765), which 
included the Javanese, Minang, Bugis, Achehnese and other ethnic groups, such as Arabs, Chinese and Indians. Some of them held important posts as palace officials, and had family relationships with Perak royals through marriages. The multiethnic presence at Perak courts among other things were recorded by Raja Chulan when the sultan of Perak opened up new settlements in Pulau Chempaka Sari as in the example below:

Maka segala orang isi bandar yang dahulu itu habislah dipindahkan ke situ sekaliannya. Adapun orangnya berbagai-bagai jenis bangsanya daripada Keling, Melayu dan Bugis dan Minangkabau dan Cina, maka terlalulah ramai bandar itu. Maka segala orang Cina dibubuh pula pada suatu tempat sama-sama Cina. Maka beraturlah rumah berlapis-lapis di seberang Pulau Chempaka Sari itu

(All the people who were in the city were moved there. There were all types of races, the Indians, Malays, Bugis, Minangkabau and Chinese, and the city became very crowded. All the Chinese were placed together in one location. Therefore houses were lined up row upon row on the mainland of Pulau Chempaka Sari.)

\section{MYTHS OF MALAY LAWS}

Before this, scholars have conducted studies on the practice of Malay laws as described in Sulalatus Salatin using various themes and focus of discussion. ${ }^{5}$ One recent viewpoint was made by John N. Miksic in 2014 via his book Singapore \& The Silk Road of the Sea 1300-1800 published by NUS Press Singapore. In this book, Miksic reread Sulalatus Salatin and tried to link it to various archaeological evidence found in Singapore at present. ${ }^{6}$ Among other things, the archaeological study in Singapore discovered a site regarded as the Malay Wall and the ancient town of Singapore located around Singapore river now. At this site is also located the Singapore trench which was where Sang Rajuna Tapa was cursed and morphed into stone for his betrayal in opening the city gates for the Majapahit Army.

According to Sulalatus Salatin (A. Samad, 1996:69-70), Sang Rajuna Tapa's betrayal was an act of revenge towards the ruler of Singapore who had condemned his daughter to death by impalement in public. Betrayal and treason to one's king and country is given huge prominence in the covenant between a king and his subjects, a myth of ancient Malay laws which is probably still believed in till today. Whatever the reason, the Malay subjects 
are forbidden to go against his king and country, and a curse or calamity after the betrayal will befall the people in many forms.

Miksic (2014:152) also discussed the story "The attack of the garfish" at Singapore beach which in his opinion "It is not a fantasy that people can be killed in this manner." According to Sulalatus Salatin (A. Samad Ahmad, 1996: 67-68) the attack of the garfish is closely related to the myth of Malay laws that something would befall the ruler who acted cruelly towards his subjects. The cruelty of the Singaporean king according to the text is described through his act of condemning to death a religious person by the name of Tuan Jana Khatib from Pasai who is said to have shown how knowledgeable he was to the queen. Not long after that, the Singapore seashore was attacked by garfish, a tragic occurrence which had never happened before, thus the people were ordered by the king to form a wall of defence against the garfish attack. The attack was finally stopped by the fast thinking of a smart boy who asked the king to build a wall out of banana trunks. Unfortunately, this smart boy was put to death by the king as a result of slanders against him by the elite group who were envious of him.

Several of these law related incidents that happened in Singapore clearly had unique mystical or spiritual characteristics, very much related to extraordinary elements and ancient beliefs, a form of law that today would be be regarded as mythical. However, the basis of law was still there whenever the king decided to punish his subject who were deemed to have committed some crime. Except that there is another power that decides the fate of the kings who punish with cruelty, possibly the power related to Hindu-Buddhist beliefs that were in line with the way of life of the kings and people who lived in Singapore then. The sultan of Singapore who killed a religious person and a smart boy led to the deterioration of the people's lives until in the end Singapore was destroyed when attacked by enemies. It is difficult to prove the authenticity of this law-related incident but modern archeological studies by Miksic perhaps can provide some answers.

\section{CUSTOMARY LAWS}

According to Sulalatus Salatin after Raja Kechil Besar converted to Islam, he changed his name to Sultan Muhammad Shah. He then established various rules and system of administration that became the customary laws of the Malacca sultanate at that time, including in matters of clothing and yellow coloured items, owning gold, white umbrella, language, ritual of 
paying obeisance, and so on. ${ }^{7}$ During the reign of Sultan Muzaffar Shah, he ordered that the laws be written down in a book so that the rules would not be in conflict. There is a great possibility that this book of laws is the Undang-Undang Melaka (Legal Codes of Malacca Sultanate) also known as Hukum Kanun Melaka.

Customary laws are replete with the element of harshness especially those which involve the interests of kings and dignitaries. The person who commits a crime would receive a heavy sentence, either the death sentence, torture, huge penalty and so on. Undang-Undang Melaka recorded several cases of harsh punishments in Malacca in the past, such as for stealing a king's property, lying about the king's words, non-payment of taxes, slander and so on. In addition, there are cases of harsh laws for those who cause injury to others, abduct someone's wife, commit sexual crimes and so on. According to Undang-Undang Melaka, the person who lies about what the king said will receive the death sentence or have his tongue split and the skin of his head peeled off (Liaw, 1976:86)

Treason against the ruler evokes the question of imposing harsh laws with no limits. Anyone who is accused of an act of treason against the ruler would certainly face only one form of punishment, that is death, and this sentence extends to family members of the accused and all his property would be confiscated as well. Even more unfortunate, the traitor would be tortured in the most abject manner, impaled and his corpse would not be given a proper burial, instead it would be displayed to the public, probably until it rot and dried up after days in the open. The harshness of laws on treason have been recorded in Malacca, Perak, Pahang, Kedah, Riau, Patani and other states. The ruler would use his absolute right or absolute immunity to protect his position and interests through the use of the laws on treason including on those among the court nobles who attempt to seize power.

In Tuhfat al-Nafis (1991:575) a story is told about Raja Merkung and Panglima Kaman who were sentenced to be beheaded and impaled for an act of treason against the sultan of Riau. In Hikayat Patani (1992:50), there is a story about Raja Kali who attempted an act of treason against Raja Kuning for which he was caught and sentenced to death. In fact his palace was pulled down, all his followers, family, children and grandchildren, male and female were killed and even "the fetus in the belly was cut open and thrown away". This law on treason which took place in Patani's history led to various acts of cruelty outside the limits of humanity, but that was the reality when kings tried to curb their traitorous subjects. 
The matter of harsh laws as recorded in Sulalatus Salatin was discussed by Abdul Rahman (1993), by reexamining the incident whereby Bendahara Seri Maharaja was put to death by Sultan Mahmud Shah. According to him, the Malay society accepted the harshness of the laws except if the laws were accompanied by cruelty. That is why, the incident of the cruel murder of Bendahara Seri Maharaja was criticised by the author of Sulalatus Salatin as being the cause for the fall of Malacca into the hands of the Portuguese. However, the discussion by Abdul Rahman Haji Ismail only evaluated the incident as an example of cruelty in the practice of Malay customary laws in Malacca, but in actual fact, the killing of Seri Maharaja and his whole family was not the practice of customary laws but the law of the jungle which went beyond the limits of what the laws and customs of the Malay sultanate should have been.

At the same time, not all the Malay customary laws were harsh, as there were many practices that reflected moderation and gentleness, in line with the philosophy of moderation of the Malay society. Undang-Undang Melaka also gave some measure of choice to the accused, either to redeem his sin by giving gold or just by taking an oath in the mosque. There were also crimes that required the accused to return a stolen good or to ask for forgiveness in public. However, the actual practices involving smaller crimes and the choice of punishment undertaken were not recorded widely in Sulalatus Salatin since this monumental work is focused more on bigger crimes such as treason against the king.

\section{TUN PERAK AND HIS CHARISMATIC LEADERSHIP}

Tun Perak's name is synonymous with the rise of Malacca as a strong state, an economic and political power in the Malay world during the 15th century. Tun Perak was the son of Bendahara Seri Wak Raja Tun Perpatih Serdang during the reign of Sultan Muzaffar Shah. Originally, Tun Perak served as a village head in Kelang, but his talents and wisdom brought him up the ladder of leadership at the court of Malacca until he became the Bendahara Paduka Raja (prime minister or grand vizier ) to four sultans, that is Sultan Muzaffar Shah, Sultan Mansur Shah, Sultan Alauddin Riayat Shah dan Sultan Mahmud Shah. As a great grand vizier, Tun Perak was respected by the sultan of Malacca and was involved in all aspects of running the palace, including administration, customs, laws, religion, trade relations, dominions, security, diplomatic matters and so on. Such a position raised Tun Perak to 
become a big name among the Malay elites (Syed Zulfida, 2008) who was very influential among the sultans, the senior members and the people of Malacca and also the people in the territories under its protection. ${ }^{8}$

As a great prime minister, his personality was not formed entirely by the sultan of Malacca and the palace environment, on the other hand these traits were already embedded in his character. Many episodes in Sulaltus Salatin showed his wise characteristics as a leader and a thinker since he started his service at the palace thus he quickly gained the attention and trust of the sultan of Malacca. His courage and wisdom were tested many times while leading the Malaccan army in fighting off Siam's invasion. His handling of political issues was very far-sighted and this can be seen through the incident when the Malays and the Indian Muslim group led by Seri Nara Diraja almost came to a head. This conflict was resolved after Seri Nara Diraja married Tun Perak's sister, Tun Kudu.

After his appointment as bendahara, Tun Perak immediately showed his leadership skills in helping the sultan of Malacca carry out the administration of the country. The author of Sulalatus Salatin recorded many instances of Tun Perak's ability and wisdom when he was in the presence of the Sultan, the senior members of the court and the common people. Tun Perak emerged as a leader with calibre and charisma in his time. In fact, to the author of Sulalatus Salatin (A. Samad, 1996:94), Tun Perak was one of the three wise people in Nusantara at that time, the first in Majapahit, Patih Aria Gajah Mada; and in Pasai, Orang kaya Raja Kenayan; and in Malacca, Paduka Raja, that is Tun Perak." According to Kamus Dewan (2005:679) the charisma of a leader can be defined as "the qualities (leadership, attraction) or certain traits of an individual that enable him/her to influence or be a motivator to others".

Among other instances, Tun Perak's charisma is evident in the incident whereby his son Tun Besar was killed by Raja Muhammad because the rattan ball kicked by Tun Besar hit the prince's headgear (A. Samad, 1996: 152-53). This incident caused Tun Perak's followers to seek revenge for Tun Besar's death but they were stopped by Tun Perak with these words "because of our custom a Malay subject shall not commit treason but this prince we shall not serve." Sultan Mansur Shah finally listened to Tun Perak's words by ordering Raja Muhammad to leave Malacca. Raja Muhamad later became sultan of Pahang (Sultan Muhammad Shah).

The charisma of a leader is an issue that is often brought up in works on Malay governance in which kings and senior members of the court are advised to acquire quality, calibre or good leadership traits and be 
of high moral standing. Works such as Taj al-Salatin, Bustan al- Salatin and Thamarat al-Muhimmah provide guidance on how a king or a highranking person can acquire a good personality in order to lead the people and country effectively, specifically with those qualities which are based on fairness in Islamic teachings. Ideally, the king and his officials should help each other and both should be of good personalities. A just king will not be able to govern his state effectively if the officials are cruel, and vice versa. The wisdom of a high ranking official is really needed to help the king rule with intelligence and grace. The philosophy of a close bond between the king and his officials is one of the important factors for the success of the sultan of Malacca under the guidance of Bendahara Paduka Raja Tun Perak. Other than Tun Perak, Malay historiograhies have also given accounts of some kings and high ranking officials who were charismatic leaders during their times, among them Sultan Iskandar Dzulkarnain in Perak (Hikayat Misa Melayu), Raja Haji in Riau (Tuhfat al-Nafis) and the reign ${ }^{9}$ of queens in Patani (Hikayat Patani)

\section{SULALATUS SALATIN AND THE NUSANTARA SOCIETY}

In Sulalatus Salatin, there are many stories and incidents that involve the various Malay ethnic clusters in the Nusantara realm. Every person or ethnic group had their own strengths and skills, as well as their own particular issues. Tun Bahara, a Pasai man is said to be good at chess until he became the chess champion during his time. He could play chess while reciting the syair or singing the gurindam (A. Samad, 1996:154). Raja Haru is reported to be a warrior who was an excellent elephant handler (A. Samad, 1996:178). Raja Maluku is mentioned as being very skilled in playing sepak raga to the extent that no one could challenge him. ${ }^{10}$ Raja Maluku's skill in playing sepak raga was outstanding and showed a very high skill in sports in those days (A. Samad, 1996:180).

Adapun Raja Maluku itu terlalu pandai bersepak raga. Maka segala anak tuan-tuan yang muda-muda pun bermainlah sepak raga dengan Raja Maluku, dan Raja Malukulah menjadi ibu. Setelah raga itu datang kepadanya, maka disepaknya raga itu seratus kali, dua ratus kali, maka baharulah diberikannya itu ditunjukkannya, tiada salah lagi. Setelah itu maka ia duduk di atas kerusi berhentikan lelahnya, dikipas orang dulu. Maka segala orang muda-muda itu disepaknya, serta datang raga itu kepada Raja Maluku maka disepaknya, berpenanak nasi raga itu di atas, tiada turun lagi, melainkan apabila hendak 
diberikannya pada orang lain, demikianlah peritahunya Raja Maluku itu bersepak raga, dapat dibawanya naik tangga.

(Raja Maluku is really skilled in playing sepak raga. Therefore the young sons of the nobles began to play sepak raga with Raja Maluku and Raja Maluku became the "mother". When the ball comes to him, he kicks the ball a hundred times, two hundred times, only then he would offer it to show how, with no mistakes. After that he sits on the chair to rest a while, with someone cooling him with a fan. Then he kicks the ball when it comes to him and the ball stays in the air, it doesn't come down until he decides to give it to someone else, that was the way Raja Maluku played sepak raga, and he brought it up the stairs.)

In Sulalatus Salatin, all law cases are narrated by its author to alternate with the stories of the Malay sultanate in Malacca, probably in order to show the power of the sultans in ruling its protectorates or to show how great its warriors were in resolving the problems that took place in the territories under the control of Malacca. As the supreme power over the states under its protection, Malacca should be able to guarantee the safety of the ruling king, the subjects and the territory itself. In return, all its protectorates should acknowledge the sultan of Malacca's dominance (often described as paying obeisance to Malacca) and obey the customary laws of the territories at that time. ${ }^{11}$ Several examples of such cases involving customary laws of Malacca's protectorates, including those which are related to Bendahara Tun Perak, can be summarized as follows:

\section{Haru's Emissary Ran Amok in Pasai}

The ruler of Haru (usually written as Aru) sent Raja Pahlawan as the emissary to Pasai. In Pasai, the ruler of Haru's letter was wrongly read by the khatib such that the word salam (greetings) was misread as sembah (prostrate). This made Raja Pahlawan furious and he ran amok killing people at the court of Pasai (A. Samad, 1996:176). Raja Pahlawan and his follower were then killed by the guards in Pasai. This incident caused enmity between Pasai and Haru. From the law point of view, Raja Pahlawan's act of running amok is against all customary laws in the Nusantara realm, especially if it happened in another person's palace. Perhaps he was an emissary with a warrior's heart but what he did was reason enough for Raja Pasai to kill him and his followers. Death sentence is a harsh law but it is an appropriate 
punishment for Raja Pahlawan who ran amok. A war between Pasai and Haru was avoided due to the intervention of the army led by Hang Tuah and Paduka Tuan, the son of Tun Perak. ${ }^{12}$

\section{Indera-Lingga War Due to Loss of Face}

The ruler of Inderagiri by the name of Sultan Nara Singa was the son-in-law of the sultan of Malacca. He was enemies with Maharaja Isap who had run off to Lingga, a protectorate of Malacca (A. Samad Ahmad, 1996:216). Sultan Nara Singa attacked Lingga and captured Maharaja Isap's family members. This made Maharaja Isap very angry and ashamed and he reacted by smearing his face with charcoal. He challenged anyone from among his subjects to remove the charcoal from his face. This challenge caused a war between Inderagiri and Lingga. Finally the sultan of Malacca managed to pacify the two parties and a war was avoided. In the context of Nusantara society at that time, the act of smearing the face with charcoal was a symbol of great shame and must immediately be rectified. From the law and governance point of view, the peace resolution proposed by Malacca as the dominant power over Inderagiri and Lingga was justifiable in order to maintain peace for the people under its protection.

\section{Semerluki from Mengkasar Attacks Ujong Tanah}

Semerluki was the son of Keraeng Majiko, the sultan of Mengkasar who ruled over the Meluluki territory. It is told that Semerluki coveted his aunty who was the seventh wife of his own father (A. Samad, 1996:154-156). This evoked the wrath of Keraeng Majiko who then drove Semerluki away who then robbed and looked for women that he desired in Ujong Tanah. Semerluki's aggressions towards UjungTanah reached the ears of the sultan of Malacca as Ujong Tanah was under the control of Malacca. An army led by Hang Tuah finally succeeded in driving off Semerluki from Ujong Tanah. Incest is highly forbidden in all the customary laws in Nusantara, including that of the Islamic religion. From the law and governance point of view, what Hang Tuah and the Malaccan army did in driving away an evil, violent and incestuous prince was justifiable in order to maintain the dignity of a territory under the protection of the Malacca sultanate. 


\section{The Ruler of Siak from Pagar Ruyung Refuses to Pay Obeisance to Malacca}

The ruler of Siak by the name of Maharaja Parameswara who came from a line of kings in Pagar Ruyung was found to have refused to pay obeisance to Malacca (A. Samad, 1996: 150) The sultan of Malacca was furious and thus sent an army to Siak. Finally, Maharaja Parameswara was killed, the state and people were conquered. Malacca at that time received a lot of captured booty. The refusal by Maharaja Parameswara in acknowdging Malacca's dominance had challenged the sultan of Malacca's position as the supreme power over occupied territories and would certainly be inviting an attack. Maharaja Parameswara's stubbornness and arrogance cost him his life. Apart from that, it is the customary law that in war, the side that wins will receive a lot of captured goods from the side that loses.

\section{Ruler of Siak Killed Someone without Malacca's Consent}

Siak in the past was under the control of the Malacca sultanate empire. Therefore, any death sentence to be carried out should have the consent from the sultan of Malacca first. Trouble started when the sultan of Malacca heard about a death sentence carried out by the ruler of Siak without letting him know (A. Samad, 1996:184-85). In order to solve the problem, the sultan of Malacca sent Hang Tuah to Siak to remind the ruler there about the laws and rules of government that should be followed in the matter of meting out a death sentence to the people. There was no war or killings because the sultan of Siak realised his mistake in not following the Malaccan customary laws (A. Samad, 1996:185).

Demikianlah istiadat dahulukala, jangankan di dalam negeri Melaka itu akan dapat membunuh tiada dengan setahu raja, jika pada negeri lain sekalipun, lamun takluk Melaka, tiada dapat membunuh.

(Such was the custom in those days, in Malacca there should not be any execution without the king's knowledge, and even in another state under its protection.)

\section{The Ruler of Kampar Refuses to Pay Obeisance to Malacca}

The sultan of Malacca received news that the ruler of Kampar, Maharaja Jaya from the Minangkabau line refused to acknowledge Malacca's dominance 
(A. Samad, 1996:148). Consequently, an army was sent to Kampar to fight Maharaja Jaya. Finally Maharaja Jaya and his prime minister, Tun Demang were killed and the Malaccans seized a lot of goods and the city was burnt. Once again, the harsh Malay customary laws were imposed on the ruler of Kampar who had refused to acknowledge Malacca's dominance.

\section{Tun Perak Invades Indera Pura}

Sultan Mahmud Shah commanded Bendahara Tun Perak to invade Indera Pura which at that time was under the control of Siam. The invasion led by Tun Perak succeeded in defeating Indera Pura and Maharaja Dewa Sura was captured and brought to Malacca. Since Maharaja Dewa Sura was an expert in knowledge of elephants, he was jailed but treated well by Tun Perak. Indera Pura's name was changed to Pahang and Maharaja Sura was released and became a teacher in the study of elephants in Malacca.

\section{Hang Tuah from Sulawesi}

A story is told about Sultan Mansur Shah wishing to befriend Raja Mengkasar in Sulawesi and so he asked Tun Perak. Tun Perak's reply was "the best of your job your highness is to have more friends than foes". Sultan Mansur Shah was happy with this reply so he asked Tun Perak to compose a letter to the ruler of Sulawesi. This episode reflects the charisma and diplomacy of Tun Perak which succeeded in building good relationships between Malacca and Sulawesi. In addition, in Sulalatus Salatin (A. Samad, 1996:103-05) the origins of Hang Tuah is made known, that he was a Bugis by the name of Daeng Mempawah. At the age of 12 he was sent to the sultan of Malacca as a serving-boy. His father was Raja Bajung from Sulawesi. The name Hang Tuah was given by Sultan Mansur Shah when Daeng Mempawah arrived at the palace. Therefore, according to the version in Sulalatus Salatin, Hang Tuah was a Bugis from Sulawesi, but learned to be a warrior while he was in Malacca. His deeds and services largely involved the upholding of the laws and maintaining peace in several states in the Malay world. In other words, Hang Tuah was a Malay warrior with Nusantara world characteristics. This version of Hang Tuah's origins is obviously different from that in Hikayat Hang Tuah which says Hang Tuah was the son of Hang Mahmud, a fisherman who lived in Sungai Duyong (Kassim, 1997:22).

Those are some examples how the Nusantara world was described in Sulalatus Salatin, in particular those involving the question of power and 
customary law practices in the territories under Malacca at that time. All these cases happened during the time of Tun Perak while he was the prime minister in Malacca and had a role in advising the sultans of Malacca regarding actions that had to be taken towards the subjects in the territories that were facing such law issues. All implementation of the death sentence must be made known to the sultan of Malacca as recorded in Clause 5 Undang-Undang Melaka (Liaw, 1976:68). The state that disobeyed would be attacked, the city destroyed, property confiscated and most probably the citizens captured and made to become servants or slaves. Hence, it was not surprising to see many slaves in Malacca that were from Nusantara communities, to the extent that laws on servants and slaves had to be specifically drawn up in UndangUndang Melaka to handle issues pertaining to their lives.

Through a comprehensive style of writing, the readers of Sulalatus Salatin are brought from one area to another in the Nusantara world, giving a new experience of the situations in the administration of the Malay states outside Malacca. This style of writing also shows the creativity of the author of Sulalatus Salatin who had a vast knowledge of the Malay Nusantara world at that time. However, the main focus of the author is still on the administration by the Malacca sultanate which was filled with a mixture of success and conflicts including that which involved the Nusantara ethnically diverse society living in the cosmopolitan city.

\section{THE PRACTICE OF CUSTOMARY LAWS IN MALACCA}

The absolute power of the sultan of Malacca in implementing the laws onto his subjects is a traditional heritage of the government of Malay rulers. During the times when the king was regarded as supremely powerful and was obeyed wholeheartedly by the people, anything that came out of the mouth of kings were laws that must be obeyed by the people without question or discussion, a form of absolute power at the highest level, highly respected and honored by all. When the Malacca Malay sultanate became a strong civilization, followed by the spread of the Islamic religion, bit by bit, the absolute power of the sultans began to be curbed by the court officials through the creation of laws, religion and customs which were designed by wise senior members. Like it or not, the Sultans of Malacca had to give their consent. Later, the emergence of Undang-Undang Melaka shows how the absolute power of the Malacca sultans diminished around the early part of the 15th century. Some of the law practices in the historiographic works can be summarized 
in the following episodes, in particular those that involve the diverse ethnic Malays of Nusantara who lived in Malacca then:

\section{A Javanese Ran Amok}

The author of Sulalatus Salatin tells the story of a Javanese in the throes of a fever and coughing badly. Several young men who were there laughed at him. He was utterly embarrassed and started running amok and killing people by using a Sundanese knife. The Javanese was finally killed by Hang Tuah. For that Hang Tuah was rewarded with a new set of official costume and his title as admiral was maintained (A. Samad, 1996:119). In the context of the law, running amok was a huge crime and the punishment was the death sentence. Although in Clause 4.8 Undang Undang Melaka, a person who is shamed by another who had slapped him can kill the latter within three days of the incident (Liaw Yock Fang, 1976:76) but in Clause 6.1 Undang Undang Melaka it is forbidden to run amok to the extent of killing others (Liaw Yock Fang, 1976:70). Therefore, the death sentence meted out to that Javanese was an appropriate resolution for the law and governance. Hang Tuah's brilliance is shown through his act of killing the Javanese by using the Sundanese knife belonging to that man himself.

\section{Patih Adam Claimed What was Promised}

Patih Adam was the pangeran of Surabaya who was in Malacca and he claimed that Seri Nara Diraja promised to marry him off to a princess by the name of Tun Minda (A. Samad, 1996:210-12 ). However, Seri Nara Diraja denied he had made such a promise and this made Patih Adam very angry and vowing to "rape Tun Minda". He then bribed Seri Nara Diraja's housekeeper and tried to abduct Tun Minda. All 40 of Patih Adam's followers were finally killed by Malaccan warriors. Patih Adam threatened to kill Tun Minda if they tried to kill him. In order to save the situation, Patih Adam was married off to Tun Minda whom he then brought back to Java.

The above incident calls to mind several questions of law. Every promise must be fulfilled, what more that made by a sultan or a high ranking official. For Patih Adam, the words of a leader was a promise that must be carried out. The denial made by Seri Nara Diraja caused a misunderstanding with Patih Adam until he had to turn aggressive to make them fulfil their promise. However, Patih Adam's act of breaking into Seri Nara Diraja's house and wanting to rape and abduct Tun Minda was a big crime and was punishable by death. 
This matter is recorded in Clauses 4 and 12 of the Undang-Undang Melaka(Liaw Yock fang, 1976:68 \& 82). Therefore the action taken by the Malaccan guards in killing off all the followers of Patih Adam were appropriate. In fact, the housekeeper who received the bribe from Patih Adam should also receive a harsh punishment or even be killed.

The law aspects become even more interesting when Patih Adam took the step of abducting Tun Minda, making her a hostage and threatening to kill her. Since Seri Nara Diraja loved his daughter who had become a victim of circumstances, he finally gave in by accepting Patih Adam as his son-inlaw. Possibly, the consideration was made to assure Tun Minda's safety or the safety of the pangeran of Surabaya or perhaps he remembered that he had made such a promise to Patih Adam. In this matter, the act of Seri Nara Diraja to marry off his daughter to Patih Adam resolved a law matter and restored peace and safety to both parties.

\section{Tun Isap Fled to Pasai, Haru and Brunei}

It is told that Tun Isap went to Tun Dewi's house and killed Tun Ali Sandang who was at Tun Dewi's house at that time (A. Samad, 1996:194-95). The killing took place after Tun Isap received "sirih" from Sultan Mahmud Shah. What Tun Isap did was a big crime and could be given the death sentence. To avoid punishment, Tun Isap fled to Pasai, then to Haru and later to Brunei. However, Tun Isap could not find peace living as a fugitive in those countries because his loyalty lay with Malacca. Therefore Tun Isap returned to Malacca. Sultan Mahmud Shah ordered Tun Isap to be tied up and brought to Seri Wak Raja to ask for forgiveness, Seri Wak Raja being a family member of Tun Ali Sandang. However once Seri Wak Raja set eyes on Tun Isap he bashed in his head with a pointed stick, and Tun Isap died.

The episode whereby Tun Isap was killed by Seri Wak Raja shows how the question of law involving murder in the past was given a lot of attention by the high-ranking elite. Although Tun Isap managed to flee to Pasai, Haru and Brunei, when he returned to Malcca, his crime in killing another person came back to haunt him. His effort to apologise did not succeed in saving his life, although a gesture of apology was one of the ways to redeem oneself as recorded in Clause 14.1 Undang Undang Melaka ( Liaw, 1976:88).

In the previous context, the action of killing Tun Isap by Seri Wak Raja by using a pointed stick also gives rise to some issues. Did Seri Wak Raja defy the sultan's efforts to get a family member to forgive Tun Isap? To Seri Wak Raja this matter did not arise because Tun Sandang was a family member. 
At that juncture Seri Wak Raja upheld the customary law of an eye for an eye, that a killing should be repaid by death of the perpetrator of the crime. This eye for an eye law is also recorded in Clauses 5.3 and 18.4 Undang Undang Melaka ( Liaw Yock Fang, 1976:70 ). Sultan Mahmud Shah did not take any any action against Seri Wak Raja because he loved Seri Wak raja who was a brilliant elephant handler in Malacca in those days.

\section{PROTESTS AGAINST SULTAN OF MALACCA}

The might of the sultan of Malacca who had absolute power in governing and law implementation did not mean that he enjoyed one hundred percent loyalty from his subjects. In certain situations, there were also cases of citizens who tried to protest against the absolute power of the Sultan, discreetly or in the open. From one aspect, such an action can lead to treason against the ruler and thus should be given capital punishment. In another aspect, the action of disobeying the sultan's decrees shows bravery that had a basis and reasons of its own. Other than Sri Wak Raja who defied the Sultan's command, there were several incidents that involved high-ranking officials defying the sultan of Malacca's orders, some of which are summarised as follows:

\section{Seri Nara Diraja Saves Hang Tuah}

There was an incident when Hang Tuah was accused of being in close proximity with one of the court ladies and hence was condemned to death by Sultan Mansur Shah (A. Samad, 1996:130-31). However, Hang Tuah's lfe was saved by Seri Nara Diraja when the latter hid him in Hulu Melaka. Seri Nara Diraja did so as Hang Tuah had rendered a lot of services and the crime he committed was not to the extent of meriting a death sentence. This incident portrays the wisdom of Seri Nara Diraja who did not follow the sultan of Malacca's commands blindly.

\section{Hang Jebat turned traitor}

In Sulalatus Salatin (A. Samad, 1996:138-43) there is a story about Hang Jebat who turned traitor against Sultan Mansur Shah to take revenge on the sultan who had condemned Hang Tuah to death. What Hang Jebat did caused injuries or death to many in the effort to kill him. Finally Hang Jebat was killed by Hang Tuah. As punishment Hang Jebat's corpse was thrown into the sea and his wife and children killed. Apart from that, the soil around 
his house pillars were also dug out and thrown into the sea as well. Hang Jebat's act of killing many goes against the custom of a Malay warrior and leader and thus it was justifiable that he be killed. Although there are views that Hang Jebat was trying to uphold justice but the cause of justice should not be at the expense of cruelty beyond limits. ${ }^{13}$

\section{Seri Udani Mocks Sultan of Malacca}

It is told that Peringgi in Malacca was on his way to attack Sultan Mahmud Shah's position in Bintan (A. Samad, 1996:278). In order to counter the attack, Sultan Mahmud Shah ordered the guards of the palace to invite Temenggung Seri Udani to the palace to make preparations for military defence. The first palace guard failed to bring the temenggung to the place because according to the temenggung he was "still trying to determine how much of his wealth had been lent to others". The arrival of the second palace guard also failed to bring the temenggung as the latter was in the midst of recording all his wealth and slaves which was still not completed. For the third time Sultan Mahmud Shah ordered the Temenggung Seri Udani to present himeself at the place immediately and to put off the counting of his wealth which had already entered the third day and the third night. After everything was written down, Temenggung Udani immediately sailed to Kota Kara to counter Peringgi's attack and he died there. Sultan Mahmud Shah then read temenggung's letter which recorded his wealth and assets, after which he realised that the Temenggung who had lived a poor life was actually mocking him ( A. Samad, 1996:279)

Patik pacal yang tua, dianugerahi nama Temenggung Seri Udani, lagi dijadikan panglima, empunya sembah ke bawah duli Yang Dipertuan, Yang Maha Mulia. Barang maklum duli tuanku, itulah banyak bilangan harta dan hamba sahaya patik itu, yang disuratkan tiga hari tiga malam: Pertama harta patik itu, talam tiada berbibir lagi pesuk satu; dan bokor pecah alas ternang Pahang sumbing satu; dan pinggan retak Cina satu; dan mangkuk semawa retak satu; piring karang satu; periuk tembaga putus bibir satu; belanga Keling tembaga retak satu; dan budak tiga orang, Si Berkat namanya, berkayuh di buritan, lagi membawa pedang; Si Lamat seorang namanya, duduk menimba ruang, lagi membawa epok; Si Tuakal seorang namanya, berkayuh di haluan, lagi membawa pengudut; itulah banyak bilangan harta dan hamba sahaya patik itu. Dan akan patik ini tiadalah mengadap ke bawah duli Yang Dipertuan lagi; insya-Allah taala, jika Kota Kara alah, patik itu mati. 
(I, your old humble servant, awarded the title Temenggung Seri Udani, proclaimed a warrior, am writing to your Highness, the most Honorable. This is to inform you that the amount of wealth I have are the following which I have recorded in three days and three nights: one bent tray without a rim, one broken and chipped Pahang metal tray, one cracked Chinese plate, one cracked greeting bowl, one crafted saucer, one copper pot with a broken rim, one cracked Indian copper pot, and three servants, Si Berkat rows at the back and carries a sword, si Lamat bails out water and carries the epok, Si Tuakal rows in front and carries the pipe; that is all my wealth and my servants. And I your humble servant will not have an audience with your Highness, God willing, if Kota Kara falls, I will perish.)

\section{SLANDER AND CONFLICT OF JUSTICE}

The wide-ranging situation of Sulalatus Salatin's narration which went beyond borders and cultures in Nusantara did not mean that the authors sidelined matters involving Malay society in Malacca. For example, in the incident involving Raden Kelang, the son of Sultan Mansur Shah and Puteri Galuh Cendera Kirana from Java (A. Samad, 1996:170) it was told that Raden Kelang who was playing in Kampung Keling was attacked by someone who had run amok. All Raden Kelang's bodyguards fled leaving Raden Kelang to fight the crazed man. Finally, Raden Kelang and the crazed man died. When he heard about the incident, Sultan Mansur Shah ordered all the bodyguards of Raden Kelang to be arrested and killed.

During the reign of Sultan Alauddin Riayat Shah (A. Samad, 1996:17375) it is told that the sultan of Malacca cracked down on the incidents of theft and robbery in Malacca. All the thieves who were caught were put to death and some had their hands cut off. Sultan Alauddin also decreed that Bendahara Tun Perak build a hall at the four corner junction in the middle of the city to store the people's stolen property which were to be returned to the rightful owners. As a result of the implementation of harsh laws, theft and robbery in Malacca were wiped out at that time. The story about Sultan Alauddin's bravery and strictness in fighting thieves showed the very attributes of a fair and just king as is often mentioned in works on Malay governance.

In another incident, Laksmana Khoja Hassan stabbed to death the Minister Tun Perpatih Hitam and his son Tun Hussein for being disrespectful in front of Bendahara Seri Maharaja (A. Samad, 1996:240-41). This particular incident reached the ears of Sultan Mahmud Shah who then praised Laksmana for following the customary rule, that one who is disrespectful in front of a 
minister is deemed to be disrespectful towards the sultan of Malacca. The harshness of this law can be seen in this incident but those were the customary laws of the Malacca sultanate then.

Looking deeper into Sulalatus Salatin, we will be able to see how the author presents the stories in a more complex manner when narrating about the lives of kings and the elites in the court of Malacca. The style of writing no longer just tells about separate episodes as in describing the stories of kings in their territories, or when telling about certain incidents related to crimes committed by individuals. On the other hand, the stories are now interrelated, until it reaches a climax with tragic solutions. In the complexity of the stories, is embedded the issue of complicated laws that can raise many questions on the system of justice and values of governance of the kings and elites of Malacca.

The focus of discussion is definitely on the reign of Sultan Mahmud Shah, the sultan who is said to have brought all sorts of problems in the administration of Malacca, a sultan who was filled with greed and self -indulgence, was revengeful, would not investigate further, practised favouritism and other corrupt deeds, until his name is tarnished as a sultan who should have administered his kingdom fairly. It was easy for the authors of Sulalatus Salatin to put the blame on Sultan Mahmud Shah because according to history, Malacca fell to the Portuguese during his reign. The weaknesses of Sultan Mahmud Shah have been recorded as the cause of Malacca sultanate's downfall until today. Therefore, it is not surprising that in Sulalatus Salatin many of Sultan Mahmud Shah's bad qualities have been described by the author, one by one, arrayed and interrelated until the downfall of Malacca.

The Sulalatus Salatin's author is of the opinion that Sultan Mahmud Shah had very low ethical values as a ruler. He was a sultan who broke the covenant and the legacy of the Malacca sultans by committing many corrupt acts and cruelty. Is that really the true character of Sultan Mahmud Shah? Or is there a possibility that all the recorded shortcomings of the sultan were deliberately written by the author of Sulalatus Salatin for some particular reasons?

The question above is raised as we look back at several stories of the sultan's corruptness and shortcomings which are described in Sulalatus Salatin, including those that have been exaggerated. The story of the sultan seeking the hand of Puteri Gunung Ledang for instance is a metaphor for decadent behaviour beyond the limits of humanity and is targetted especially towards Sultan Mahmud Shah. Similarly, there is the story of Sultan Mahmud who is 
said to have consented to the murder of Tun Ali Sandang, his brother, Raja Zainal and that of Bendahara Tun Mutahir and family. Where the practice of law is concerned, clearly Sultan Mahmud was a sultan "who was governed by his wants and desires" and did not deserve to be respected and obeyed by the people. However, is it true that Sultan Mahmud Shah was a cruel tyrant during his reign?

The old saying "the pen is mightier than the sword" holds true because Sulalatus Salatin's sharp words against Sultan Mahmud Shah seem to have left a negative impact in the minds of readers regarding the shortcomings of Sultan Mahmud Shah. Religious upbringing, tasawuf teachings and good administrative legacy received by Sultan Mahmud since young did not influence the sultan to become a just ruler. Furthermore, young sultan Mahmud Shah was under the care and nurture of the Prime Minister Tun Perak who was his uncle. There are at least nine administrative legacies in Sulalatus Salatin that contain advice for the previous sultans and also for Sultan Mahmud Shah, including the legacy from the Prime Minister Tun Perak which reads as follows (A. Samad, 1996:191):

Setelah itu maka terdengarlah kepada Sultan Mahmud Syah, Bendahara sakit sangat. Maka baginda pun berangkatlah mendapatkan Bendahara Paduka Raja. Maka Bendahara pun menyembah pada baginda, maka sembah Bendahara Paduka Raja, "Ampun tuanku, pada perasaan patik yang dunia ini luputlah daripada genggaman patik, melainkan negeri akhiratlah sematamata patik hadapi, segala anak buah patik, petaruh patiklah ke bawah duli tuanku. Hendaklah tuanku jangan dengar-dengarkan akan sembah orang yang tiada sebenarnya, jikalau tuanku dengar-dengarkan akan kata orang yang fitnah, akibat tuanku menyesal kelak. Bahawa yang kehendak nafsu itu daripada waswas syaitan alihi 'l-la' anat. Banyak raja-raja yang besar-besar dibinasakan Allah kerajaannya sebab menurutkan hawa nafsu syaitan."

After that Sultan Mahmud Shah heard that the Bendahara was very ill. Therefore the sultan departed to visit Bendahara Paduka Raja. The Bendahara paid obeisance to the sultan and said: My apologies your Highness, I feel that my life here in this world is ebbing away, the hereafter will be the one I am going to, all my family and relatives I surrender to you. Your Highness, do not listen to complaints by other people that are not truthful, if your Highness listen to their slander, you will regret it later. The urgings of desire are the work of the devil. Many kingdoms have been destroyed by Allah when we follow the the devils' lures. 
Obviously, while Bendahara Tun Perak was alive, Sultan Mahmud Shah was still a good king and did not show any evil tendencies in his character, The prime minister's charisma had a strong influence on Sultan Mahmud Shah, including where customs and implementation of laws were concerned. In one incident (A. Samad, 1996:187) Seri Maharaja had influenced the king to kill an individual who had committed a small crime. ${ }^{14}$ Tun Perak reprimanded Seri Maharaja immediately with these words: "Hey Seri Maharaja! You teach a tiger cub to eat meat, one day it will then eat you." Tun Perak's admonition was a form of education for Sultan Mahmud Shah. In fact, when Sultan Mahmud Shah ascended the throne, the description of the sultan was full of praise:

Sebermula akan Sultan Mahmud Syah pun bangat besar, tahulah baginda memerintah kerajaan sendirinya, terlalu baik sikapnya, tiada berbagai pada zaman itu. Jika keris tempa Melaka yang panjang tengah tiga jengkal itu dijadikan baginda pendua, tiada kelihatan dari sebelah.

When Sultan Mahmud Shah became big and mighty, he knew how to govern his own kingdom, his attitude was excellent, not different for that era. If the kris forged in Malacca that was three fists in length was made a copy by the sultan, it would not be different from the other side.

However, this was the last praise bestowed on Sultan Mahmud Shah, for as soon as the words were written, the author began to narrate stories of his bad behaviour and shortcomings. The Prime Minister Tun Perak had passed away and was replaced by his brother, Bendahara Tun Perpatih Putih (Bendahara Putih) who was of a different character altogether. ${ }^{15}$ The sultan's act of cruelty began with the incident known as "the spear almost flew to the chest". Something does not seem right with the sultan's character as suddenly he was portrayed as a cruel sultan carrying out evil and depraved acts. From a just sultan like a forged kris, suddenly he was shown to have harrassed Tun Bijaid's wife until Tun Bijaid almost committed an act of treason by hurling a spear towards the sultan's chest.

Sultan Mahmud Shah's anger towards Bendahara Tun Mutahir was due to the latter marrying off Tun fatimah to Tun ali without first informing the sultan. The sultan's anger erupted to the point of sentencing Bendahara Tun Mutahir and his family to death. In this episode, the author effectively portrays Tun Mutahir's acceptance of the punishment, perhaps in order to accentuate the cruelty effect of Sultan Mahmud Shah. However, in this tragic 
episode, the author of Sulalatus Salatin has been able to hint at the cause of the incident, which is defamation followed by sedition and corruption among the senior members of the palace, all of which involved those from the Indian Muslim group who were in service at the court of Malacca at that time.

In the episode "The Reason that Triggered the Cruellest Punishment"(A. Samad, 1996:155-259), the author of Sulalatus Salatin tells the story of a quarrel between a trader headman by the name of Nina Sura Dewana and Raja Mendaliar. To surprise his rival, at night Nina Sura Dewana went to Bendahara Seri Maharaja Tun Mutahir's house bringing with him 10 katis of gold. This particular incident was discovered by an Indian called Kitul who then told Raja Mendaliar a lie, that Bendahara Seri Maharaja and Nina Sura Dewana were plotting to kill Raja Mendaliar. When he heard the slander, Raja Mendaliar went to Laksmana Khoja Hassan the same night bringing with him gold, gems and beautiful costumes, and began to spread the slander that Bendahra Seri Maharaja wanted to commit treason against the sultan of Malacca. All the slanders and seditious words were passed on by Laksmana Khoja Hassan to the sultan of Malacca which led to the killing of Bendahara Seri Maharaja and his family.

Slander, sedition and corruption among the high-ranking officials were the main cause of the killing of Bendahara Seri Maharaja and his family, furthermore the slander was about an attempt by a senior official to seize power from the sultan. The only form of punishment that could be meted out was the death sentence. Although the author of Sulalatus Salatin did refer to Sultan Mahmud's feeling of revenge towards Bendahara Seri Maharaja for marrying off Tun Fatimah to Tun Ali, it would have stayed as revengeful feelings only. ${ }^{16}$ But these feelings could reignite when a spark of fire is present, and in this case the spark was the slander and corruption of the senior officials themselves. Bendahara Seri Maharaja and his family members which included Seri Nara Diraja, Tun Hassan Temenggung and Tun Ali the husband of Tun Fatimah were also put to death. The plot born out of defamation, sedition and corruption happened very quickly, in one night it was planned and carried out successfully, as if the fires of treachery had already spread like cancer among the high-ranking officials and the Indian Muslim traders in Malacca at that time.

Did Sultan Mahmud Shah act unfairly when he sentenced to death Bendahara Seri Maharaja and family? On the surface, it looks like was, to add to all the other bad attributes of the sultan which have been narrated by the author. The sentence was carried out hastily without a thorough 
investigation. This time, the problems in law implementation not only involved the various Malay ethnic groups in Nusantara, but also a group of Indian Muslim traders and officials who were rich and cunning in Malacca during those days. Slander, sedition and corruption could not be controlled any longer, but had spread wildly and became a cancer that erupted and destroyed the good and civilized way of life of the Malays.

From the law point of view, defamation accompanied by sedition and corruption was the nucleus or mother of all evil that took place in the Malaccan palace at that time. Nina Sura Dewana, Raja Mendaliar, Kitul and Laksmana Khoja Hassan had reignited the law of the jungle in Malacca with money, property and wealth as their bets. They wanted to buy all, in the name of their power and wealth for their own interests. If Laksmana Khoja Hassan could blatantly pass on slanders and act treacherously towards the sultan of Malacca, it is obvious that the law of the jungle had returned to the court of Malacca, biding its time to destroy all vestiges of just laws that had been established for a long time.

When Sultan Mahmud Shah realised his mistake he conducted a thorough investigation. Consequently, Raja mendaliar was sentenced to death with his whole family. Kitul was sentenced to be impaled crosswise with his wife and children too. The soil around the pole for impalement was dug out and thrown into the sea. Only laksmana khoja hassan escaped the death penalty because the sultan had vowed never to kill him (A. Samad, 1996:259).

The harsh and heavy sentences meted out to Raja Mendaliar and Kitul were commensurate with their crimes, although it was too late since their victims had already been killed. According to the covenant and ancient law myths, a cruel king who kills his subjects without good reason will face the retribution of loss of crown and kingdom. That was the fate of Sultan Mahmud Shah who was forced to flee from one place to another until his death in Kampar.17 The downfall of Sultan Mahmud Shah truly reflect these words in Taj al-salatin that "power is lost because of cruelty" (Khalid, 1992).

\section{LESSONS IN LAW FROM SULALATUS SALATIN}

With regard to customary laws, the author of Sulalatus Salatin has shown how the various errors in law implementation that took place in Malacca and the territories under its control managed to be corrected by the wise sultans and senior members of the palace, especially the prime minister, Bendahara 
Seri Paduka Raja Tun Perak. He was a great administrator, a renowned expert on customs and laws in the history of Malacca. Punishment was meted out according to the type of crime committed including heavy sentences, especially the death sentence. The people who were from various ethnic groups were ready to face the punishment meted out because the punishments were the same among the Malay governments in Nusantara at that time. Even if the punishment was harsh, the people could still tolerate, as long as they understood that they had committed the crime. In this context, the incidents involving laws and punishment recorded in Sulalatus Salatin are in line with the customary law records found in Undang-Undang Melaka.

At the same time, the author of Sulalatus Salatin also admonished those cases in which there was abuse of laws in the palace of Malacca as a result of defamation and corruption of the elites. By giving the title "The Reason that Triggered the Cruellest Punishment", the author of Sulalatus Salatin is issuing a sharp reprimand about the incident, that the implementation of the law here was no longer just strict and harsh, but it was cruel and brutal. Unfortunately, the blame for this cruel implementation was placed on Sultan Mahmud Shah as the last sultan of Malacca, for which he had to bear the consequence of breaking the covenant made by the Malay kings and therefore he lost his throne. In actual fact, the main cause of the cruel punishment was due to the slanders, seditious remarks and corruption of the elites from the Indian Muslim community who were power crazy and acted out of self interest. All these terrible acts of law implementation happened after the death of Tun Perak.

There are many lessons in laws and governance that can be learnt from the incidents of slanderous acts that took place during the time of Sultan Mahmud Shah in Malacca. Anyone who holds the reins of power should possess a stable character supported by knowledge and strong religious principles to act as a defence against slanders and deception by others. This is among the messages on leadership that is the core of a work like Sulalatus Salatin, Bustan as-Salatin or Thamarat al-Muhimmah. Slander and corruption are a frightening cancer, even more dangerous than all the harsh punishments that are available, especially if carried out as a conspiracy by parties that are very cunning. Slander or defamation can be said to be a "disastrous ambition" that destroys "all the ideal ambitions that are the historical heritage of the Malays" (Syed Hussein, 2001). Sultan Mahmud Shah failed to confront and adjudge the slanderous and seditious attacks that 
were brought to him, probably because he no longer received wise counsel from the prime minister Bendahara Paduka Raja Tun Perak.

Sultan Mahmud Shah's character was obviously not as strong as Sultan Iskandar Dzulkarnain Shah in the history of the Perak sultanate. In Hikayat Misa Melayu (2015:52-54) it is told that there was an an attempt by an Indian by the name of Pir Muhammad who spread lies to the Dutch that the sultan of Perak wished to cut off ties with the Dutch. These slanders almost caused a war between the Dutch and the state of Perak but due to Sultan Zulkarniain Shah's wisdom at that time, all the tension caused by the slanders was able to be stopped from spreading. Raja Nazrin Shah (2004:21) while commenting on Sulalatus Salatin and Undang-Undang Melaka noted three main traits of a king as follows:

The qualities required by the Kanun for being a Ruler were that he should be merciful (ampun), generous (murah), courageous (perkasa), and firm in his rule.

Tuhfat al-Nafis $(1991: 195,282,292)$ is one of the historiographic works that record many incidents and slanderous acts that took place among the palace elites in Riau and the territories under its control, especially those that involved conflicts between Malays and Bugis. However, according to Raja Ali Haji, all the problems of slander managed to be overcome wisely by the Riau rulers so that they did not lead to drawn-out conflicts. For example, in the there is a case of defamation saying that the Bugis had broken into Tun Wangsa's house ( Tuhfat al-Nafis, 1991:282 ). When this was investigated thoroughly by Raja Abdul Jalil, it was proven that the defamation had no basis whatsoever. If Raja Abdul Jalil had not conducted a thorough investigation, the possibility is that punishments that went beyond justice would have been meted out. For Raja Ali Haji, a man who likes to spread lies is as follows (Tuhfat al-Nafis, 1991:292) "If a man who has a foul mouth and wants to destroy someone. It means that his manly weapon is not sharp."

\section{CONCLUSION}

As a conclusion, laws cannot be separated from the just values of leaders and those in power as implementers of the law, whether to uphold or destroy all regulations determined by the society. The stupidity of a leader will reignite laws of the jungle towards the people who are weak and unresisting. Tun Sri Lanang's wealth of knowledge as the author of Sulalatus Salatin is highlighted through records of incidents involving law implementation 
towards the various Malay ethnic groups in Nusantara, including the Arabs, Indians and Chinese. All of them could accept the harshness of the Malay customary laws as long as they were implemented on the right basis.

The issue of the fairness of laws is given special attention in works of governance that counsel and guide rulers or kings in carrying out their responsibilities of governing in the best way possible. The historiographic works such as Sulalatus Salatin also lay out lessons on how a king can be aided by charismatic and knowledgeable officials leading to a prosperous country. The official referred to is the prime minister Paduka Raja Tun Perak. Conversely, if the king is weak and foolish he will be deceived by slanders of the officials that are cunning and full of tricks, until finally the king will have to bear the consequences of a bad reputation for a long time.

Ancient works are not just material for remembrance, but embedded in them are philosophies and lessons for those who know how to value and understand them deeply, including the descendants of the Malay race in future. This is one of the main motives of the writing of Sulalatus Salatin by Tun Seri Lanang in 1612. Harshness of punishment can strengthen a nation , but slander and corruption can destroy and vanquish it, thus destroying the culture and civilization of humankind. The charismatic leadership of a prominent figure such as Bendahara Paduka Raja Tun Perak who left behind the true history and heritage of Malay statehood should continue to be given attention in more scholarly and in-depth researches in future.

\section{NOTES}

1. Punishments such as to be submerged in water, or the hand is put in oil or lead are recorded in Undang-Undang Melaka (Liaw Yock Fang, 1976:88) as a direct influence from Hindu beliefs. Punishments based on water and fire are recorded in chapter 8 Laws of Manu (Doniger \& Smith, 1991:164)

2. In the context of this article, ethnic Malays refer specifically to the generations of Malay race from various tribes or ethnic groups including Javanese, Bugis, Banjars, Minangs, Achehnese, Patani and others, and also include those of Arab, Chinese and Indian Muslim descent who had assimilated with the Malays, practice the Islamic religion and the customary way of life of the Malays.

3. In the introductory part of Sulalatus Salatin (A. Samad, 1996:2) it is related that Tun Seri Lanang received the order to compose or compile Sulalatus Salatin while he was in Batu Sawar Daru'l-salam. The name Batu Sawar was again mentioned by Tun Seri Lanang at the end of Sulalatus Salatin when he described his appointment as Bendahara Johor, in addition to mentioning several other places such as Seluyud (Seluyut), Tanah Putih, (Batu Sawar), Makam Tauhid, Pasir Raja, Tanjung batu, Tanjung Surat and Johor Lama. All these places are in the area which is now Kota tinggi, Johor, the original 
place where the rulers of Johore are buried. The name Johor Lama recorded by Tun Seri Lanang in Sulalatus Salatin refers to Kota Johor Lama or Kampung Johor Lama that is now located on the left bank of Johore river, about 30 kilometers from the town of Kota Tinggi.

4. Apart from Malacca, the other Malay city states that were also centres for traders from all over the world and the Nusantara realm include Acheh, Palembang, Brunei Darussalam, Singapore and Riau.

5. See Hooker 1970, Liaw Yock Fang 1976, Abu Hassan Sham 1995, Noor Aisha 2006 \& Kratz 2011.

6. John N. Miksic's study, a project under the sponsorship of National Museum of Singapore and the National University of Singapore. Among the archaeological findings is the story of the mighty Badang who could throw a big rock to Kuala Singapura, which is believed to have happened at Singapore river which is the middle of Singapore city now (Miksic, 2014:12 \&152). The hill of Singapore is now known as Fort Canning which is the place of several old mausoleums, including that of Raja Iskandar Shah who is regarded as a saint by Singapore's community (Miksic, 2014:219). According to Miksic (2014:151) the lion-like animal described in Sulalatus Salatin was "clearly not a lion" but more like "a mythical beast called janggi" that existed in a legend in Minangkabau. Miksic went on to say (2014:151) the name Temasik was changed to Singapura round 1390 and the name Singapura probably originated from the names of Buddhist kings in the past. The symbol of the lion is often found on carvings of Asoka kings who were Buddhists in India since the 3rd century B.C.

7. Part of this custom is recorded in Clauses 2 and 3 Undang-Undang Melaka.

8. See several early studies on Tun Perak in Muhammad Yusoff Hashim (1992), Muhd Yusof Ibrahim (2009), Baharudin Ali Masrom Al-Haj (2010)

9. A study on the charisma of Malay leaders should be done in the future in a more scholarly manner and guided by more comprehensive historiographic works and a more scientific application of the theory of charisma.

10. According to Reid's(1988:200) records, the Dutch was said to have seen a Maluku for the first time playing sepak raga around 1599, and the skill of the Maluku in playimg sepak raga is described as: "the extraordinary skill of the players, all standing in a ring and passing the ball to one another".

11. In Undang-Undang Melaka, the customary laws of the territories under Malacca's control is stated in clause 4 as follows (Liaw Yock Fang, 1976:68): "Clause 4 states the laws of the state and the tributaries and the farms under its control". Therefore, all citizens living in Malacca and also the people in the states under Malacca's control are subject to the customary laws of the sultanate of Malacca, or specifically the UndangUndang Melaka.

12. The person who runs amok is a grave danger to others and almost all customary laws impose a heavy sentence. In Tuhfat al Nafis, many stories are told about people running amok who receive harsh punishments

13. In the version given in Sejarah Melayu by Shellabear (1996: 98-101) and the version of Sulalatus Salatin from MS Raffles Malay 18 by Muhammad Haji Salleh (2009: 97-100), the character who committed treason was Hang Kasturi. But the version of Sulalatus Salatin by A. Samad Ahmad says that it was Hang Jebat and Hang Jebat appears as the that treasonous person in Hikayat Hang Tuah (Kassim, 1997:353-94).

14. According to Sulalatus Salatin (A. Samad, 1996:146) Tun Perak also had high intuitive 
knowledge so much so he could see "light" as the sign that Tun Mutahir would become great minister. Sulalatus Salatin (A. Samad, 1996:148 ) also describes Tun Perak's honesty in keeping Sri Nara Diraja's inheritance which was to be given to Tun Mutahir and his siblings when they grew up. Tun Perak was able to keep that trust.

15. Sulalatus Salatin (A. Samad, 1996:191) describes Bendahara Tun Perpatih Putih as a spendthrift.

16. According to the custom of the Malacca sultanate (A. Samad, 1996:251), when the sultan was without a wife, he should take for his wife the daughter of the prime minister and she would become the queen. Although Bendahara Seri Maharja knew of this custom, he did not want to follow it. Instead he wanted his daughter to marry Tun Ali. This goes to show that the Bendahara Seri Maharaja had defied a custom practiced in the palace of Malacca and this made Sultan Mahmud Shah feel revengeful towards Bendahara Seri Maharaja.

17. See academic discussion on this matter in Muhammad Yusoff Hashim (1992: 32-35).

\section{REFERENCES}

Abdul Rahman Haji Ismail, 1993. "Kekerasan pada zaman Kesultanan Melayu Melaka: Penelitian berdasarkan Sejarah Melayu” in. Qasim Ahmad (ed.), Kekerasan dalam Sejarah. Kuala Lumpur: Dewan Bahasa dan Pustaka.

Abu Hassan Sham and Mariyam Salim, 1995. Sastera Undang-Undang. Kuala Lumpur: Dewan Bahasa dan Pustaka.

Defamation Act 1957 (Act 286), 2009. Batu Caves: Penerbitan Akta Sdn. Bhd. Sedition Act 1948 (Act 15), 2009. Batu Caves: Penerbitan Akta Sdn. Bhd.

A. Samad Ahmad, 1996. Sulalatus Salatin (Sejarah Melayu). Kuala Lumpur: Dewan Bahasa dan Pustaka.

Baharudin Ali Masrom Al-Haj, 2010. Ikon Dua Zaman: Tun Perak dan Tun Razak. Kuala Lumpur: Ikdas.

Doniger, Wendy \& Smith, Brian K., (eds.), 1991. The Laws of Manu. London: Penguin Books.

Hikayat Misa Melayu. (Keturunan Peraturan Istiadat Segala Raja-Raja Yang Kerajaan Negeri Perak) Karangan Raja Chulan ibni Raja Hamid. Studied and introduced by Jelani Harun, 2015. Kuala Lumpur: RNS Publication \& Yayasan Karyawan.

Hooker, V.M. (ed.), 1970. Readings in Malay Adat Laws. Singapore: Singapore University Press.

Hooker, V.M., 1991. Tuhfat al-Nafis. Kuala Lumpur: Dewan Bahasa dan Pustaka. Istilah Undang-Undang, 1998. Petaling Jaya: Sweet \& Maxwell Asia.

Kamus Dewan Edisi Keempat, 2005. Kuala Lumpur: dewan Bahasa dan Pustaka. Kassim Ahmad, 1997. Hikayat Hang Tuah. Kuala Lumpur: Dewan Bahasa dan Pustaka. Khalid M. Hussain, 1992. Taj al-Salatin. Kuala Lumpur: Dewan Bahasa dan Pustaka. Khasnor Johan, "The Undang-Undang Melaka: Reflections on Malay Society in Fifteenth-century Malacca" in JMBRAS 72, pp. 131-50, 1999. 
Kratz, E.U., 2011. "Sulalat al-Salatin dan Hikayat Hang Tuah: Sumbangan dan Pandangan Kesarjanaan Barat Terhadap Dua Karya Agung Melayu" Conference Proceeding Paper Persidangan Antarabangsa Karya Agung Melayu, 1-2 November 2011, Seri Negeri, Air Keroh, Melaka, anjuran Yayasan Karyawan dan Kerajaan Negeri Melaka.

Liaw Yock Fang, 1976. Undang-Undang Melaka. The Hague: Martinus Nijhoff.

Miksic, J. N., 2014. Singapore \& The Silk Road of the Sea 1300-1800. Singapore: NUS Press.

Mohd. Radzali Masrum, 2011. Maksim dan Ungkapan Undang-Undang. Kuala Lumpur: Dewan Bahasa dan Pustaka.

Muhammad Yusoff Hashim, 1992. The Malay Sultanate of Malacca. Kuala Lumpur: Dewan Bahasa dan Pustaka.

Muhd. Yusof Ibrahim, 2009. Tun Perak Pencetus Wawasan Empayar Melaka. Kuala Lumpur: Tinta Publishers.

Raja Nazrin Shah, 2004. The Monarchy in Contemporary Malaysia. Singapore: Institute of Southeast Asian Studies.

Reid, A., 1988. Southeast Asia in the Age of Commerce 1450-1680. Yale: Yale University Press.

Shellabear, W.G. (comp.), 1996. Sejarah Melayu. Shah Alam: Penerbit Fajar Bakti.

Siti Hawa Haji Salleh (comp.), 1992. Hikayat Patani. Kuala Lumpur: Dewan Bahasa dan Pustaka.

Sulalat al-Salatin ya'ni Perteturun Segala Raja-Raja (Sejarah Melayu) Karangan Tun Seri Lanang. Studied and introduced by oleh Muhammad Haji Salleh, 2009. Kuala Lumpur: Yayasan Karyawan \& Dewan Bahasa dan Pustaka.

Syed Hussein Alatas, 2001. Cita Sempurna Warisan Sejarah. Bangi: Penerbit UKM. Syed Zulfilda Syed Mohd. Noor, 2008. "Pentadbiran Melaka Darul 'Azim" dlm. Polemik Sejarah Malaysia 1. Kuala Lumpur: Arkib Negara Malaysia. 